\section{Securities Lending and Short Selling}

\author{
Fernando Chague ${ }^{1}$ \\ Bruno Giovannetti ${ }^{1}$ \\ ${ }^{1}$ Getulio Vargas Foundation, Sao Paulo School \\ of Economics, Sao Paulo, Brazil \\ Rodrigo De Losso ${ }^{2}$ \\ ${ }^{2}$ University of Sao Paulo, FEA/USP, Dept of Economics, Sao Paulo, Brazil
}

\author{
Alan De Genaro 3 \\ ${ }^{3}$ Getulio Vargas Foundation, São Paulo School of Business \\ Administration, Dept of Finance, Sao Paulo, Brazil
}

Received on

09/06/2018

Approved on

06/28/2019

Responsible editor:

Prof. Dr. Joelson Oliveira

Sampaio

\section{Evaluation process:}

Double Blind Review

\begin{abstract}
Purpose - The aim of this study is to offer the current view on the subject, placing emphasis on studies that use Brazilian data and that could motivate new research.

Design/methodology/approach - A bibliographic review of related studies and a secondary database.

Findings - The contribution is to introduce this topic for the academic community in Brazil. We also present the main descriptive information for this market and its economic and policy implications.

Originality/value - We contribute to the literature by summarizing the main works in the field, focusing on the Brazilian market, which has very detailed data and great potential for further studies.
\end{abstract}

Keywords - Securities Lending. Short Selling. Regulation 


\section{Introduction}

Securities lending, particularly stock lending, attracts the attention of market participants, academics, and regulators due to its different uses, with short selling being one of the most contentious ones.

The literature on restrictions on short selling, in particular Miller (1977), points out that restrictions on short selling could imply that stocks are overpriced. If the factors that make it unviable for investors to carry out short selling operations last for long, stock prices will remain overestimated and, thus, have low future returns until the overpricing is corrected. So, by identifying stocks that are subject to restrictions on short selling, one can identify the stocks with particularly low future returns.

There are many international studies on the effects of short selling. Some recent papers deal specifically with the Brazilian market. Therefore, the aim of this study is to present the functioning of this market and to serve as an orientation for new studies on this subject to be produced by the academic community for the Brazilian market.

The remainder of this paper is structured as follows. Section 2 presents the economic rationale and operational characteristics of stock lending, highlighting the differences between the centralized model of Brazil and the decentralized model. Section 3 describes the main restrictions on short selling adopted by different countries, especially after the 2008 crisis. Section 4 briefly presents the main studies that address the international market of securities lending, while Section 5 presents the main studies that explore stock lending and short selling using Brazilian data. Lastly, Section 6 presents the final considerations.

\section{Economic rationale and operational characteristics}

Short selling is the process by which an investor sells a stock in the market, for example, in an electronic trading venue, without necessarily having bought the stock. The non-existence of this stock in the investor's portfolio (custody) gives rise to two ways of short selling: normal and naked.

In both cases, the economic rationale is the possibility of repurchasing the stock on the equity market at a lower price and, consequently, profiting from this operation, even after including the cost of the loan.

Normal short selling begins with the loan of the asset, followed by its sale on the equity market, which is operationally a relatively simple process in virtually all countries. In the case of naked short selling, the process is different, as the investor sells on the equity market first and then seeks to borrow the stock to meet the settlement cycle in that market. If the investor is not able to borrow the asset in time to honor the sale, it results in a failure to deliver, which is subject to fines and penalties.

The market configuration of securities lending varies from one country to another. For example, in the US, stock lending is a decentralized process; the lender and borrower agree bilaterally through a brokerage firm on the loan details, including the cost of borrowing, term to termination, and, especially, the amount of collateral that the borrower will have to make available to cover the risk incurred.

In the US market, securities lending is treated as an over-the-counter (OTC) operation, carried out within an institution or between two institutions. The operation is recorded in the accounts of the institutions involved, without any record in a centralized system. As these operations are decentralized, the only limits imposed on loan operations are those imposed by the institutions, considering that these same institutions are the ones that will reap the gains from a greater volume of operations.

In Brazil, the structure is centralized; all stock lending transactions are carried out by clearing and settlement entities authorized by the Securities and Exchange Commission of Brazil (CVM). The current regulatory framework is provided by Resolution No. 3539 of February 28, 
2008 of the National Monetary Council, CVM Instruction No. 441 of November 10, 2006, and by the rules and regulations adopted by the entity providing the asset clearing and settlement service.

Historically, securities lending in Brazil, of mostly stocks, came from the need to adopt mechanisms to minimize failures in the delivery of stocks during the settlement cycle of the transactions originating from the equity market. On May 13, 1996, the then São Paulo Stock Exchange (BOVESPA) formed a subsidiary called CALISPA S.A. for the settlement of transactions carried out on the BOVESPA, including those resulting from failure to settle. Months later, the Brazilian Settlement and Custody Company (CBLC) was formed and incorporated CALISPA. This event coincided with the launch of the Securities Lending System of the CBLC, known as BTC, which constituted the securities lending system until 2018, when the $B 3^{1}$ launched the BM\&BOVESPA Securities Lending System (BTB).

The B3 is the only Financial Market Infrastructure (FMI) authorized by the CVM to provide centralized registration and settlement of securities lending transactions. In the exercise of its functions aimed at guaranteeing settlements, the B3 acts as the central counterparty (CCP) for securities lending transactions and calculates the risk associated with the transactions and the margin required from borrowers, along with the maximum limits for lending transactions associated with a given stock.

Although registration in a centralized system is required in accordance with Brazilian regulations, the negotiation phase between the borrowers and the lenders and the consequent determination of the loan $\mathrm{fee}^{2}$ is similar to the American model, where a broker actively participates in the process to find parties for the transaction. The analysis of Figure 1 shows that there is, in fact, a relationship network between brokers and that some institutions interacted actively from January 2012 to December 2014, while others tend to meet the lending needs of their clients without resorting to other brokers, making use of their own client base.

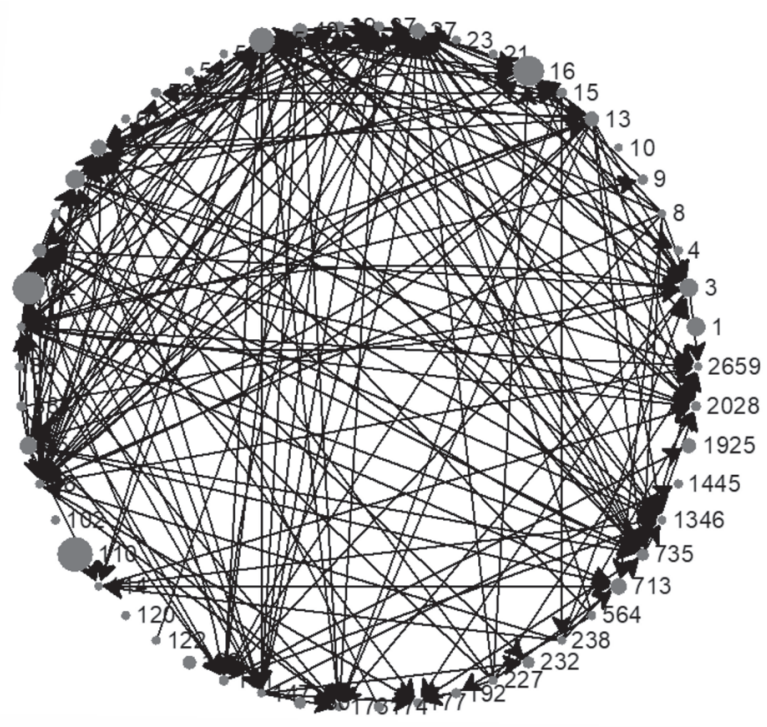

Figure 1. Relationship network

Comment: Each circle represents a brokerage house involved in the stock lending process and the arrows show the direction in which the relationship occurslender and/or borrower. Only those brokers that traded more than 1 billion reais from Jan 2012 to Dec 2014 are displayed. The size of each circle represents the financial value that the brokerage house represented in the securities lending process for the period.

As previously mentioned, the economic rationale for short selling is the possibility for the investor to buy back a stock in the future at a price lower than the sale price and, consequently, make a profit. Studies have investigated investors' informational capacity to anticipate a decline in a stock price, as will be discussed in sections 4 and 5 .

However, when the analysis is extended, a trading strategy that actively uses stock lending is the market making of options. For the investor, the lending of shares does not presuppose the expectation of a future downturn but rather a risk management strategy for his/her portfolio.

It should be noted that the stock lending process involves the temporary transfer of ownership to the borrower. Thus, the borrower is entitled to all rights, such as the right to vote, if he/ she has not sold the stock. However, with respect to proceeds, such as dividends and interest on net 
equity, the borrower is obligated under the terms of the stock lending agreement to reimburse the lender. The same reimbursement process is also applied in the case of corporate events, such as dividend payments, interest on net equity (JCP), mergers, and splits.

Thus, it can be said that the third-most regular use of stock loans is associated with a temporary transfer of rights. In this sense, the study of Mota (2017) shows that stock lending was a strategy that was extensively exploited by institutional investors motivated by regulatory arbitrage (in this case, taxes) until 2014.

Table 1 provides an overview of the Brazilian loan market, describing its evolution from 2000 till 2011:

Table 1

Evolution of the Brazilian stock lending market

\begin{tabular}{ccccc}
\hline Year & Volume (in millions USD) & $\begin{array}{c}\text { Volume } \\
\text { (\% of market cap) }\end{array}$ & $\begin{array}{c}\text { Number of } \\
\text { transactions }\end{array}$ & $\begin{array}{c}\text { Number of shares } \\
\text { involved }\end{array}$ \\
\hline 2000 & 1.560 & 1 & 2.530 & 30 \\
2001 & 2.790 & 2 & 11.953 & 60 \\
2002 & 2.428 & 2 & 22.486 & 68 \\
2003 & 4.374 & 2 & 39.044 & 74 \\
2004 & 8.903 & 3 & 78.729 & 116 \\
2005 & 24.664 & 5 & 166.494 & 135 \\
2006 & 50.496 & 7 & 271.210 & 156 \\
2007 & 124.106 & 11 & 568.592 & 220 \\
2009 & 174.568 & 13 & 627.414 & 251 \\
2010 & 137.483 & 19 & 711.987 & 241 \\
\end{tabular}

Source: Retrieved from "Short-sellers: Informed but restricted" by F. Chague, R. De-Losso, A. De Genaro, and B. Giovannetti, 2014.

Table 1 shows that the stock lending market has grown in numbers over the last decade - the financial volumes have grown, the number of transactions has reached 1 million, and the number of shares is approaching 300showing that the lending market has been actively used not only to address settlement failures but also for carrying out investment strategies.

According to the aggregated data provided by the $\mathrm{B} 3$, the composition of the three main types of lenders in September 2018 is: local investment funds, corresponding to $45.3 \%$ of the value traded by lenders; international investors, corresponding to $29.5 \%$; and individual investors, corresponding to $20.5 \%$.

When observed in disaggregate form, the data show high heterogeneity among the rates in the loan market, as described in Table 2. 
Table 2

Evolution of the stock lending market

\begin{tabular}{|c|c|c|c|c|c|c|c|c|c|}
\hline \multirow[b]{2}{*}{ Ticker } & \multirow[b]{2}{*}{$\begin{array}{c}\text { No. of } \\
\text { contracts } \\
(2)\end{array}$} & \multirow[b]{2}{*}{$\begin{array}{c}\text { Number of } \\
\text { Shares } \\
(3)\end{array}$} & \multirow[b]{2}{*}{$\begin{array}{c}\text { Value (in } \\
\text { thousand } \mathbf{R} \$ \text { ) } \\
(4)\end{array}$} & \multicolumn{3}{|c|}{$\begin{array}{l}\text { Rate \% of Lender Remuneration } \\
\text { (commission-free) }\end{array}$} & \multicolumn{3}{|c|}{ Fee $\%$ paid by the borrower } \\
\hline & & & & $\underset{(5)}{\operatorname{Minimum}}$ & $\begin{array}{l}\text { Average } \\
(6)\end{array}$ & $\begin{array}{l}\text { Maximum } \\
\quad(7)\end{array}$ & $\underset{(8)}{\operatorname{Minimum}}$ & $\begin{array}{l}\text { Average } \\
\text { (9) }\end{array}$ & $\begin{array}{l}\text { Maximum } \\
\quad(10)\end{array}$ \\
\hline CIEL3 & 3251 & $140,879,136$ & $122,365.60$ & $2.12 \%$ & $8.68 \%$ & $10.00 \%$ & $6.05 \%$ & $9.38 \%$ & $13.99 \%$ \\
\hline ITUB4 & 2536 & $100,289,855$ & $251,567.90$ & $0.04 \%$ & $0.09 \%$ & $0.23 \%$ & $0.07 \%$ & $0.15 \%$ & $1.73 \%$ \\
\hline PETR3 & 1363 & $94,328,516$ & $119,273.00$ & $0.06 \%$ & $0.12 \%$ & $0.23 \%$ & $0.09 \%$ & $0.18 \%$ & $1.09 \%$ \\
\hline ITSA4 & 919 & $89,604,570$ & $50,407.91$ & $0.04 \%$ & $0.09 \%$ & $0.20 \%$ & $0.07 \%$ & $0.15 \%$ & $1.13 \%$ \\
\hline PETR4 & 2015 & $89,319,872$ & $98,158.52$ & $0.04 \%$ & $0.09 \%$ & $0.37 \%$ & $0.07 \%$ & $0.16 \%$ & $2.23 \%$ \\
\hline ABEV3 & 2366 & $78,707,474$ & $86,253.38$ & $0.03 \%$ & $0.09 \%$ & $0.26 \%$ & $0.06 \%$ & $0.18 \%$ & $1.20 \%$ \\
\hline VALE3 & 3236 & $74,205,369$ & $231,953.40$ & $0.05 \%$ & $0.11 \%$ & $0.49 \%$ & $0.07 \%$ & $0.18 \%$ & $1.94 \%$ \\
\hline BBDC4 & 2534 & $69,513,774$ & $115,679.60$ & $0.05 \%$ & $0.09 \%$ & $0.37 \%$ & $0.08 \%$ & $0.16 \%$ & $1.85 \%$ \\
\hline LAME4 & 1882 & $62,690,939$ & $56,911.00$ & $0.59 \%$ & $2.90 \%$ & $3.38 \%$ & $1.02 \%$ & $3.34 \%$ & $5.33 \%$ \\
\hline KROT3 & 2199 & $61,802,231$ & $37,074.91$ & $0.68 \%$ & $2.29 \%$ & $2.92 \%$ & $1.17 \%$ & $2.56 \%$ & $4.38 \%$ \\
\hline
\end{tabular}

Comment: Evolution of the stock lending market in the most recent period disclosed by the B3 (08/21/2018 to 09/13/2018). The table reports the 10 companies that had the highest number of shares loaned. Columns (2) and (3) denote the total values observed in the period. Columns (4)-(10) report average values. Source: B3 (http://www.b3.com.br)

Table 2 presents the 10 companies with the largest amount of shares lent during the period 08/21/2018-09/13/2018. During that period, the share borrowed the most was CIEL3, of Cielo SA, a company that acts as an acquirer in the means of payment industry.

In addition to the number of shares loaned and their corresponding financial value, Table 2 describes the fees of lenders and borrowers during the period, with the difference between the two fees representing the commission charged by intermediaries, again showing a high degree of heterogeneity among the shares.

To illustrate the effect between stocks over time, Figure 1 presents the average rate received by lenders for stocks that had records for every day during the period and where the total financial value is over 100 million reais. 


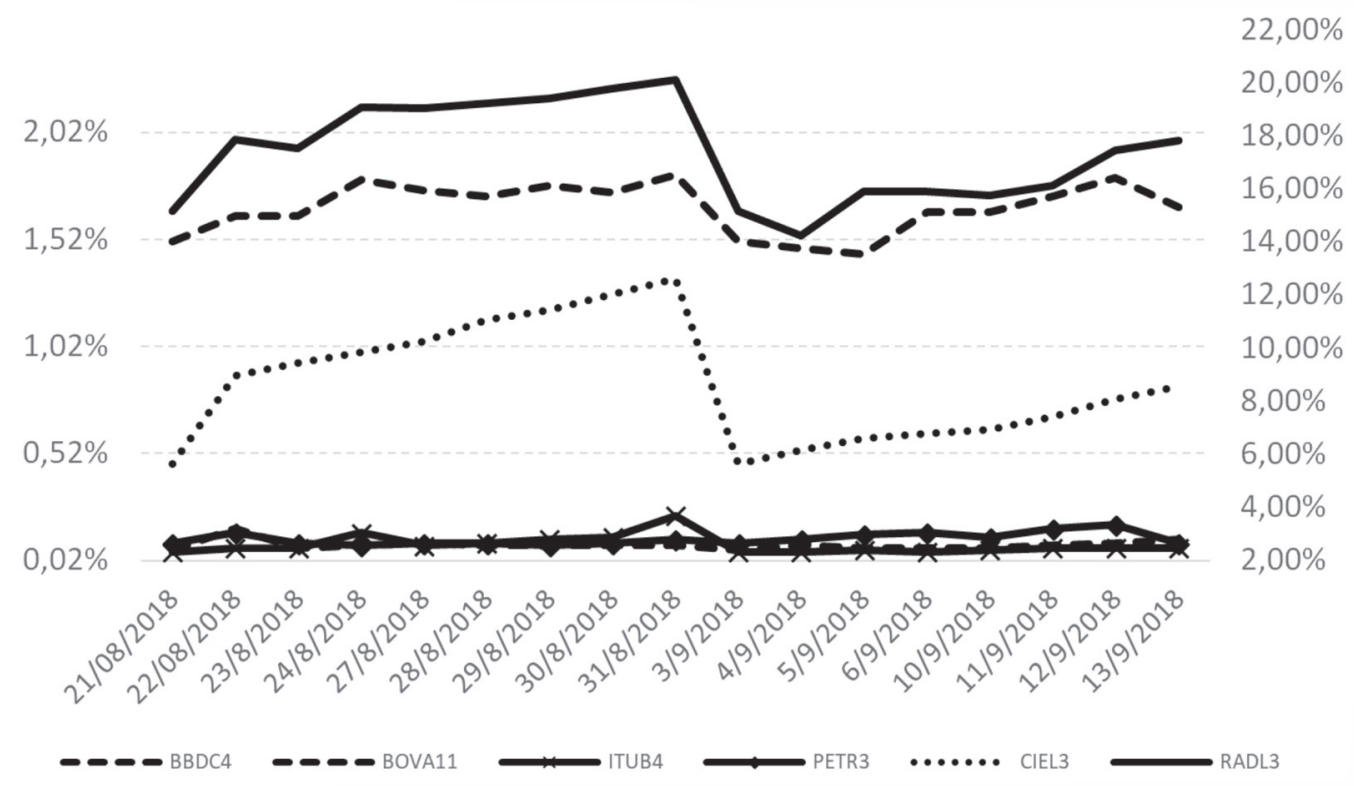

Figure 2. Average Rates Received by Lenders

Comment: Evolution of the stock lending market for the most recent period disclosed by the B3 $(08 / 21 / 2018$ to $09 / 13 / 2018)$. The chart shows the companies that had transactions for every day of the sample and that had a financial value of over $\mathrm{R} \$ 100$ million. The left axis shows the average rate received by lenders for BBDC4, BOVA11, ITUB4, and PETR3 shares. The right axis shows the average rate received by lenders for RADL3 and CIEL3 shares. Source: B3 (http://www.b3.com.br)

Figure 2 shows that there are two distinct groups of assets: stocks with loan fees below $1 \%$ (BBDC4, ITUB4, and PETR3) and stocks that are considered hard-to-borrow ${ }^{3}$, with rates above $10 \%$ (RADL3 and CIEL3).

As observed, the fees paid by borrowers are different from those received by lenders. This difference can be seen in Figure 3 for the same group of stocks. There is variability between the stocks and over time, with the differential being proportional to the fee level. Stocks with low loan rates are easily found and, consequently, there is less space for the commissions charged by the broker, while stocks that are hard-to-borrow end up with a bigger differential because of the service provided by intermediaries for finding a lender willing to lend that asset. 


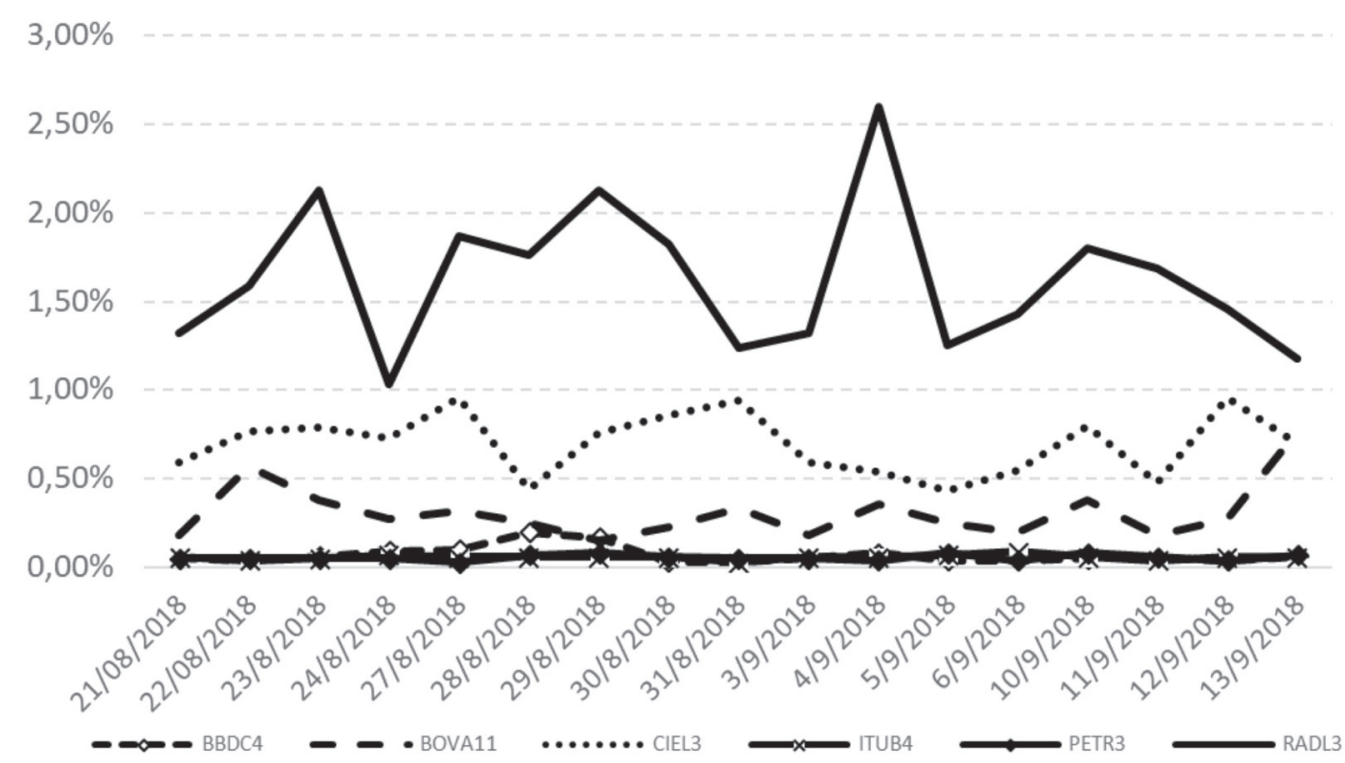

Figure 3. Differential between the fees paid by borrowers and received by lenders

Comment: Evolution of the stock leading market in the most recent period disclosed by the B3 (08/21/2018 to $09 / 13 / 2018$ ). For each share, the value represents the spread between the fee paid by borrowers and the fee received by lenders. Source: B3 (http://www.b3.com.br)

Theoretically, this differential can be attributed to the search cost of finding a stock that the borrower wants to sell but which is not available internally at the brokerage firm of origin. As shown by Chague, De-Losso, De Genaro, and Giovannettet (2017), the heterogeneity can be best seen when the fees are analyzed at the investor-broker level. In this sense, using a database that identifies only those involved in the transactions (lenders, borrowers, and brokers), finding a stock is easier for a borrower who has a good relationship with brokers who, in turn, have good relationships with frequent lenders of the stock. Based on this, a borrower is said to have low search costs if he/she is well connected to brokers who are well connected to active lenders.

\section{Short selling and its prohibitions}

As pointed out by Bris et al. (2007), short selling has been the object of bans and restrictions for almost as long as stock exchanges have existed. Regulators have argued that short selling magnifies declines in asset prices, and therefore should be limited or prohibited during times of high stock market volatility.

There have been several episodes where short selling was prohibited. The stock market crisis of 1929 or the 2000 technology stocks crisis are examples of these events. Although their impacts were significant at the time, these prohibitions were limited to the US stock markets. The real estate market crash, which began in 2008, is one example where regulators across the board restricted or banned short selling.

As the US was the first country to feel the impact of the financial crash, it was also the first to restrict ${ }^{4}$ short selling. The first ban was in effect from July 21, 2008 until August 12, 2008 and affected all naked short selling transactions. The second and more restrictive measure adopted by the Securities Exchange Commission (SEC) was the temporary prohibition of any form of short sale of approximately 1,000 shares from September 19 to October 8, 2008, to stabilize the fire-sale pressure on the equity market. 
In the UK, the Financial Securities Authority (FSA) announced emergency measures for a complete prohibition on short selling with stocks of financial institutions on September 18, 2008

Prohibitions also intensified in continental Europe, where countries implemented different measures to restrict the short selling of stocks and credit default swap trading. Due to its fragmented and discretionary nature, the European Commission started developing common rules for all member states.

The final version ${ }^{5}$ of the proposals was approved and made mandatory for member states from November 1, 2012. Among them, naked short selling of stocks, sovereign CDSs, and other sovereign debt securities was prohibited. Additionally, investors were obligated to disclose, to the competent entity, all their short positions exceeding $0.2 \%$ of the total outstanding shares of the company (free-float), as well as any $0.1 \%$ increase in this amount. Furthermore, short positions of companies that were more than $0.5 \%$ of their free-float had to be disclosed to the market in a wide and unrestricted way. In the case of short positions in sovereign bonds, the European Securities and Markets Authority (ESMA) periodically disclosed the threshold above which short positions had to be reported.

During the same period, the Securities and Exchange Commission of Brazil (CVM) decided not to apply any bans or prohibitions on short selling in Brazil because it considered that, unlike in other countries, the existence of a centralized environment and regulatory framework with selfregulation were, in themselves, sufficient to ensure the proper functioning of the markets and would avoid excessive use of short selling transactions.

Although not prohibited or banned, there was one case where the CVM implicitly prohibited short selling in a particular circumstance. This was through CVM Instruction ${ }^{6}$ number 530, in which the Commission prohibited the purchase of shares of companies issuing follow-on stocks by institutions or individuals that had short sold the shares of the company in the 5 days prior to the determination of the offer price. The aim was to prevent manipulation attempts to lower the sale prices in offerings, which would have harmed publicly traded companies already in the market and allowed investors to receive shares in the public offer at a lower price.

\section{Literature review with international data}

Since Miller's seminal paper (1977), the impact of short selling restrictions on financial markets has been the subject of numerous empirical studies. One of the most widely anticipated effects is that the interactions between heterogeneous valuations and restrictions on short selling would lead to overpricing. Thus, both the increase in heterogeneity and restrictions on short selling would put upward pressure on prices. While several studies have convincingly illustrated (either in cross-sectional or time-series analyses) the effect of variations in heterogeneity, determining the effect of variations in short selling restrictions is a major challenge.

The second classic conceptual reference is the study of Diamond and Verrecchia (1987), where the authors, based on a rational expectations framework, examined the impact of short selling restrictions on the distribution of prices and on the speed at which new information is incorporated into asset prices. The authors found that: (i) reductions in restrictions on short selling, with the possibility of trading options, increase the speed at which negative information is incorporated into prices; and (ii) prolonged periods of inactivity in the trading of a stock is an indicator of bad news for that company and, consequently, a drop in the price, because informed investors in possession of bad information would be prevented 
from materializing their perceptions due to the restrictions on selling.

The empirical evidence that verifies the effects of short selling on stock prices is not unanimous. Although there is some evidence that short selling restrictions lead to stock overpricing, for example that of Jones and Lamont (2002), Ofek and Richardson (2003), Ofek, Richardson and Whitelaw (2004), and Cohen, Diether, and Malloy (2007), other studies find that short selling restrictions have an insignificant effect on prices, like those of Battalio and Shultz (2006), Diether, Lee, and Werner (2009), Beber and Pagano (2013), and Kaplan, Moskowitz, and Sensoy (2013).

Against the background of the restrictions imposed in the 2008 crisis and their subsequent consequences, where naked short selling would have exacerbated a fall in stock prices, Fotak et al. (2014) conducted a study on the impact of these transactions on the future price of assets. The authors found that there is no significant statistical evidence to support the idea that naked short sales contributed to the collapse of large financial institutions. In fact, the authors found that failure to deliver increased significantly after abnormal negative price changes and not before, as claimed by regulators to justify the numerous restrictions that were imposed.

Also with the goal of understanding the impact of the numerous restrictions and bans many countries imposed during the 2008 crisis, Bebber and Pagano (2013), after controlling for other variables, presented statistical evidence which indicates that the short selling prohibitions during the crisis contributed to a worsening in the liquidity of stocks through an increase in the bid-ask spread and in illiquidity indicators such as the Amihud illiquidity measure.

The authors also investigated whether these negative effects on liquidity disproportionately affected certain stocks and whether they were more pronounced for the stocks of smallcap companies. They found that in countries characterized by a significant presence of smallcap stocks, prohibitions were associated with higher increases in bid-ask spreads. In addition, the adverse effect on liquidity resulting from the prohibitions was stronger for stocks that do not have listed options than for stocks that do, suggesting that the availability of an options market allowed investors to take short positions on stocks affected by the prohibition.

Bebber and Pagano (2013) showed that short selling prohibitions worsen the price discovery process, especially when it comes to negative news, which is in line with theoretical predictions and previous empirical findings. Finally, they concluded that short selling bans in the financial sector were not significantly correlated with excess return, except in the US, where the correlation was positive and significant, which is in line with the results of Boehmer, Jones, and Zhang (2013). However, the result found for the US might reflect the fact that bailouts occurred concomitantly with the bans and, therefore, might be spurious. Thus, in contrast to regulators' claims, the general evidence indicates that short selling prohibitions left stock prices unchanged at best.

Saffi and Sigurdsson (2011) analyzed the impact of short selling restrictions on price discovery, which is the ability of a share to adequately and timely incorporate the flow of available information. The authors used a large database of approximately 17,000 shares in 26 countries to create a data panel of stocks, in which the quantity offered and loan rates can be related to several efficiency measures, such as bid-ask spreads.

Their main findings were: (i) restrictions on short selling are associated with lower price efficiency. In general, stocks with a limited loan supply and high lending rates respond more 
slowly to market shocks; and (ii) restrictions on short selling affect the distribution of weekly returns. Stocks with a limited loan supply are associated with a greater asymmetry but not with kurtosis or extreme negative returns with a low probability of occurrence. They observed that the relationship with asymmetry seems to come from the changes in the occurrence of large positive returns and not from the occurrence of large negative returns. Therefore, they argue that regulatory concerns over short selling, where its liberalization would tend to increase sharp falls in stock prices, are actually overly conservative.

The authors concluded by presenting a cross-sectional analysis of the data, in which they found that stocks with loan restrictions and high loan rates tend to respond more slowly to shocks that impact the entire market, so easing loan restrictions would lead to an increase in the speed at which information is incorporated into prices, thus improving price discovery. Furthermore, large and liquid companies also tend to have a better price discovery process, while companies with high leverage or low book-to-market indices tend to have a less efficient price discovery process.

While the literature on the impact of short selling restrictions on future returns is vast, there is little empirical evidence linking short selling restrictions to corporate decisions. Theoretically, several authors, such as Gilchrist, Himmelberg, and Huberman (2005) and Goldstein and Guembel (2008) argue that restrictions on short selling can lead to the overpricing of stocks and cause excessive investment. Therefore, in the presence of overpricing, removing the restrictions on short selling should lead to lower stock price and investment levels.

Of course, one of the main challenges when studying this issue is to identify causal relationships when the fundamentals of the company, short selling, and stock prices are almost always determined simultaneously. In this sense, the study of Grullon, Michenau, and Weston (2015) used an experiment, resulting from a regulatory change, which reduces restrictions on short selling in a random sample of US companies to test whether capital market frictions have an effect on stock prices and corporate decisions.

The authors found that allowing short selling caused prices to fall and smaller companies reacted to these lower prices by reducing new issues of shares as well as the level of investment. These results not only provide evidence that short selling restrictions affect asset prices but also confirm that short selling has a causal impact on financing and investment decisions.

As the authors pointed out, it is surprising that an apparently small regulatory change caused impacts of this nature. They point out that the result is possibly due to the way the regulatory change was implemented and not necessarily the change itself. In other words, by focusing only on a certain subset of stocks, the SEC might have unintentionally leveraged the short selling, and that may have put this group at a disadvantage.

Based on the above argument, the authors concluded that it is not possible to generalize the results and claim irrefutably that the results would be identified equally in all companies if short selling flexibility was allowed. However, they found empirical evidence to support theoretical formulations in which decisions to invest and issue new shares are indeed sensitive to changes in asset prices.

\section{Literature review with Brazilian data}

The literature on stock lending and short selling is relatively new in Brazil, which is why we have identified only a few papers on this topic. Although studies on this subject are not frequent in Brazil, the market configuration is very propitious for academic research, since stock loans are centralized in the $\mathrm{B} 3$, which allows the data 
to be obtained in a transparent and consolidated way for all transactions and not just a sample of the market, as is usual in the US where the data comes from brokers. Below, we present in more detail the main studies that have addressed this subject in Brazil.

\section{a) Short sellers: Informed but restricted - Chague et al. 2014}

This study could be considered the forerunner of all analyses of stock lending and short selling in Brazil. The authors used a database in which they were able to identify, in an anonymous but unique and consistent manner over time, all the stock lending transactions in Brazil from January 2009 to July 2011.

According to the theory, the level of short selling can predict future short-term returns through two channels. The first channel, related to the demand for short selling, comes from the ability of short sellers to anticipate movements in stock prices and, in this way, they are said to be informed. The second is related to the supply of stock loans, in which case short sellers are often restricted; they cannot short sell as much as they want. To empirically justify which of the two effects prevail, the channels described above were denominated as information hypothesis (IH) and overpricing hypothesis $(\mathrm{OH})$, respectively.

Measuring the importance of each channel is empirically challenging since, in general, supply and demand in the stock lending market are not directly observable. The authors thus proposed an empirical strategy that identifies the effect of changes in both short selling demand and the supply of stock loans, thus allowing for IH and $\mathrm{OH}$ to be directly tested.

The strategy consists of regressing future short-term returns in relation to the total number of shares that were lent in a given week (defined by ) and the two variables representing the loan supply curve- the total number of shares offered for loan through the electronic market during that week (defined by) and the average loan rate of the loan offers during that week (defined by ).

Given the nature of the estimated effects, the regression coefficient for variable identifies the effect on stock prices in short-term demand (effect A): an increase in with the loan supply curve set by both and can occur only if the sales demand moves to the right. In addition, the regression coefficient for variable identifies the effect on stock prices of the changes to the right of the loan supply curve that occur together with the changes to the left of the short selling demand curve (B effect): an increase in with and fixed can happen only if there is a shift to the right in the loan supply along with a shift to the left in loan demand.

Estimating effects $A$ and $B$ is useful because it allowed us to jointly test $\mathrm{IH}$ and $\mathrm{OH}$ as follows: if effect $A$ is negative, it is consistent with IH. Conversely, if effect B is also negative, it is concluded that $\mathrm{OH}$ is also true because effect $\mathrm{B}$ occurs through a combination of an increase in the loan supply and a reduction in the demand for loans. The reduction in the demand for loans, given the negative sign of effect $\mathrm{A}$, should have a positive effect on prices. Therefore, the increase in loan supply decreases stock prices, which is consistent with $\mathrm{OH}$.

The authors find empirical evidence in their estimates that support both $\mathrm{IH}$ and $\mathrm{OH}$ : (i) an increase of one standard deviation in generates a 12-basis point drop in stock price within two weeks of the increase and (ii) an increase of one standard deviation in generates a 27-basis point reduction in share price in the two weeks following the increase.

Moreover, they found that while the information channel reaches its maximum effect two weeks after the shift to the right of the short selling demand curve, the restrictions on sales in the short term have long-term effects on stock 
prices, increasing monotonically for up to four weeks.

Based on these results, the authors concluded that short sellers are informed investors (IH) but, as they generally cannot short sell as much as they wish to, the prices do not reflect all the information present in the market $(\mathrm{OH})$.

b) Well-connected short-sellers pay lower loan fees: A market-wide analysis - Chague et al. 2017

The main contribution of this study is that it is the first to examine the relationship between loan rates and search cost at the borrower level. Measuring search cost that is specific to the borrower is empirically challenging, since one must measure the importance of each lender in the market, as well as the relevance and/or intensity of relationships among borrowers, brokers, and lenders.

The authors test two hypotheses:

H1: The higher the search costs faced by one borrower, the higher the loan fees paid;

H2: The higher the search costs faced by the borrowers, the greater the dispersion of the loan fees among those borrowers.

To empirically evaluate the hypotheses, it is necessary to: (i) observe all stock loans in the market and (ii) uniquely identify the borrowers, brokers, and lenders over time.

The databases used in the literature did not allow (i) and (ii) to be fully observed. Conversely, the data used by the authors allowed both (i) and (ii) to be identified, as their database included the following information: loan amount, loan fee, type of investor, unique identification of the borrower, unique identification of the broker, and unique identification of the lender for all loan contracts in the Brazilian market between January 2008 and July 2011.
To empirically evaluate the hypotheses, the authors constructed a specific search cost measure for the borrower based on the theoretical model of Duffie, Garleanu, and Pedersen (2002).

To reproduce the loan dynamics of a stock, it is known that in a typical transaction, a possible short seller contacts his/her broker requesting a specific stock for loan. The broker then searches for a potential lender within his/ her own brokerage (own inventory) or turns to another brokerage house. Hence, obtaining a share is easier for a borrower who has a good relationship with brokers who, in turn, have good relationships with the active lenders of the share.

Based on this transactional flow, a borrower is said to have low search costs if he/she is "well connected" to brokers who are "well connected" to active lenders. A borrower is said to be well connected to a broker if he/she is a major client of that broker. Similarly, a broker is well connected to a lender if he/she is responsible for a high share of the lender's business.

Since the data set allowed each market participant to be tracked over time, the authors were able to calculate: (a) how well connected each borrower was to each broker, (b) how well connected each broker was to each lender, and (c) how active each lender was in the loan market of each share.

From the calculations of (a), (b), and (c), the authors define a new variable called the borrower connection (BC), which is specific to each borrower, share, and variable over time. The $\mathrm{BC}$ variable is constructed in such a way that it is high when a borrower is well connected to brokers, who in turn are well connected to the active lenders of a given stock. Therefore, the $\mathrm{BC}$ variable should be negatively related to the borrower's search costs.

The authors performed a series of empirical analyses to understand the relationship between BC and loan fees. First, deal-by-deal panel 
regressions were performed with loan fees being explained by the $\mathrm{BC}$. The authors found evidence to support $\mathrm{H} 1$ and $\mathrm{H} 2$ that can be summarized as follows: borrowers with low connections pay significantly higher loan fees.

The authors also included non-linear effects by separating borrowers into three groups (high, medium, and low BC) and compared the average lending rate in each group. Firstly, the results show that borrowers from the low BC group pay $14.5 \%$ higher loan rates than borrowers from the high $\mathrm{BC}$ group.

Secondly, direct measures of loan fee dispersion (standard deviation of loan fee and deals range for the same share) are used to test whether loan rate dispersion is higher among low connection borrowers. Again, the authors found that the standard deviation of the loan fee and loan fee magnitude among borrowers in the low BC group are, respectively, $46 \%$ and $135 \%$ higher than the rates among borrowers in the high $\mathrm{BC}$ group.

Finally, the analysis was refined to study the in-broker variation in the loan rates. The same regressions described above were estimated, but using only those deals closed within a single broker-the largest in terms of transactions. The conclusions are the same as before: it was found that on the same day, for the same share, the broker has different loan rates for different types of borrowers.

To incorporate unobserved borrowerspecific effects that can be correlated with $\mathrm{BC}$ and lending rates, all regressions were performed on sub-samples of borrowers that share similar characteristics regarding the type of investor, volume traded, and frequency of trades. In doing so, the effect can be estimated of BC on lending rates in deals closed by similar borrowers.

For example, considering only the institutional investors, the authors found that a low $\mathrm{BC}$ institutional investor pays an $8.5 \%$ higher loan rate than a high $\mathrm{BC}$ institutional investor. Similarly, when only frequent borrowers are considered, a low BC frequent borrower was found to pay a $10.9 \%$ higher loan fee than a high $\mathrm{BC}$ frequent borrower. Finally, considering only large borrowers, it was found that a large borrower with low BC pays a $9.8 \%$ higher loan rate than a large borrower with high BC.

Once the heterogeneity in the fees was identified according to $\mathrm{BC}$, the authors wanted to disentangle the components of $\mathrm{BC}$. They pointed out that a borrower may have a high $\mathrm{BC}$ because of five components: (i) he/she is connected to many brokers; (ii) he/she has consistent relationships with his/her brokers; (iii) his/her brokers are connected to many lenders; (iv) his/her brokers have strong relationships with these lenders; and (v) these lenders have high market shares.

To evaluate the individual relevance of the five components, the authors created a flexible version of the $\mathrm{BC}$ variable, called. In the original $\mathrm{BC}$ construction, all components are active by construction, while in, those components can be disconnected. So, by lowering the loan rates in relation to , the relevance of each of the five components is estimated empirically.

The regressions revealed that four of the five components are relevant for explaining loan fees. The only component that does not add explanatory power to is component (iii) - the number of lenders to which the borrower's brokers are connected.

The fact that the number of lenders is irrelevant while the number of brokers to which the borrower is connected is relevant means that the stock lending market is less opaque for brokers than for borrowers. In other words, brokers actively involved with stock lending can update their understanding of the market with greater agility, while borrowers who participate in the loan market occasionally need to interact with various brokers to be informed of the market 
dynamics.

Finally, the authors concluded that the opacity in the OTC markets is responsible for frictions that cause consequences in loan fees: participants with a higher search cost will be subject to higher costs in loans for the same stock. Therefore, to reduce friction, they recommended increasing securities lending through electronic trading platforms instead of the current model focused on OTC trading.

c) Stock Lending Market, Short-Selling Restrictions, and the Cross-Section of Returns

- Mota (2017)

In this study, the author measured the impact of short selling on the future return of stocks through a natural experiment. This is a very interesting approach, because it made it possible to identify an exogenous factor that affected the loan fee, as well as the quantity of short positions in loan operations.

As seen in Table 1, Brazil experienced significant growth in stock lending activity from 2000 through 2011 . However, it was identified, in a granular manner, that the stock lending activity peaked in the days before the date on which companies paid interest on net equity (JCP).

This abnormal activity is related to a tax loophole that lasted until 2014, where mutual funds were exempt from the $15 \%$ tax on the payment of interest on net equity by companies.

Thus, the dynamics that drove stock lending were supported by the following logic: if a stock was loaned to a mutual fund during the distribution of JCP, the fund would receive the total dividend, regardless of the fiscal status of the lender of the stock. When the funds borrowed shares from lenders that were subject to withholding taxes, they had to repay only the net amount of the taxes that the lender earned, retaining most of the value of the taxes. These stock lending operations generated significant gains for the funds at the expense of the government, generating an abnormal increase in stock lending activity around JCP payment dates.

The increase in stock lending activity caused by these tax arbitrage opportunities restricted the supply of short selling loans during those days. Since these tax arbitrage activities were unrelated to the investors' expectations of stock returns, they provided an almost natural experiment of an exogenous variation in the availability of stock loans for short selling in the equity market.

The results showed that the increase in short selling restrictions for a stock around its dividend payment date caused a considerable increase in the price of the stock, corroborating the overpricing hypothesis also found by Chague et al. (2014). Furthermore, the author found that the average loan rate jumped fivefold, from an average of $2 \%$ of the notional value during normal periods to $10 \%$ during periods of JCP distribution, while the short positions increased from an average of $2.2 \%$ to $3 \%$.

\section{Final comments}

The stock lending market and short selling strategies are a topic of interest to investors, regulators, and academics especially, since they can be empirically validated with available data.

Many regulators have limited or prohibited short selling at different times, almost always under the pretext of preventing sharp movements in stock prices during times of financial stress, as was the case in 1929 and 2008-2009.

Several studies show that short selling bans have the following impacts: (i) they worsen market liquidity (Bebber and Pagano, 2013; Saffi and Sigurdsson, 2011), (ii) they make the price discovery process less efficient (Saffi and Sigurdsson, 2011), and (iii) they distort corporate decisions, such as regarding higher investments and the issue of new shares (Grullon, Michenau, 
and Weston, 2015). These results allow us to conclude that the negative impacts of short selling bans and restrictions on the efficiency and good functioning of the markets are clear.

The debate on stock lending and short selling is relatively new in the Brazilian context, but the same is relevant for the results found, especially in regards to policy implications, as found by Chague et al. (2017), where the opacity of the stock lending market was responsible for significant frictions that made stock lending more costly for the investor than it would have been if it were done through an electronic trading venue.

We also believe that the subject has great potential for future studies in the Brazilian academic community, in particular due to the model adopted in Brazil, where the loans take place centrally, with the identification of investors and participation of a central counterparty (CCP).

\section{Notas}

1 B3 is the company resulting from the acquisition of CETIP by BM\&FBOVESPA in 2017.

2 The loan fee that represents the total cost to borrow a share is thus the loan rate (which includes broker commission), plus a B3 annual fee of $0.25 \%$.

3 The expression 'hard-to-borrow' (HTB), although not widely used in Brazil, describes those shares that are not easily lent. In the US, brokers usually inform their clients about the shares that are on this list and have a higher loan rate or may be compulsorily used (buy-in) by the broker as a way of ending the settlement cycle or meeting the demand (recall) of the original donor. This particular item was studied by De Genaro and Avellaneda (2018) for a set of leveraged ETFs traded in the US.

4 As part of an effort to update short sale regulations, the US Securities and Exchange Commission (SEC) put into force Regulation SHO on January 3, 2005. Regulation SHO requires, among other things, that the broker has a reasonable belief that the equity to be short sold can be borrowed and delivered to a short seller on a specific date before short selling can occur. Further details and amendments are available at https://www.sec.gov/ spotlight/shortsales.shtml.

5 https://www.esma.europa.eu/regulation/trading/shortselling

6 http://www.cvm.gov.br/legislacao/instrucoes/inst530. html

\section{References}

Amihud, K. (2002) Illiquidity and stock returns: cross-section and time-series effects. Journal of Financial Markets, v. 5(1): 31-56.

Battalio, R. \& Shultz, P. (2006). Options and the Bubble. The Journal of Finance, v. 61 (5): 2071-2102.

Beber, A. \& Pagano, M. (2013) Short-Selling Bans Around the World: Evidence from the 2007-09 Crisis. The Journal of Finance, v.68 (1): 343-381.

Boehmer, E.; Jones, C. \& Zhang, X. (2013). Shackling Short Sellers: The 2008 Shorting Ban, The Review of Financial Studies, v. 26 (6): 1363-1400.

Bris, A., Goetzmann, W. \& Zhu, N. (2007). Efficiency and the Bear: Short Sellings and Markets around the World. Journal of Finance 62(3): 1029-1079.

Chague, F.; De-Losso, R.; De Genaro, A. \& Giovannetti, B. (2014). Short-sellers: Informed but restricted. Journal of International Money and Finance, v. 47: 56-70.

Chague, F.; De-Losso, R.; De Genaro, A. \& Giovannetti, B. (2017). Well-connected shortsellers pay lower loan fees: A market-wide analysis. Journal of Financial Economics, v. 123: 646-670.

Cohen, L.; Diether, K.; \& Malloy, C. (2007). Supply and Demand Shifts in the Shorting Market. The Journal of Finance, v. 62(5): 20612096.

De Genaro, A. \& Avellaneda, M. (2018). Does the Lending Rate Impact ETF's Prices? Brazilian Review of Econometrics v. 38 (2): 287-319.

Diamond, D. W. \& Verrecchia, R. (1987). Constraints on short-selling and asset price 
adjustment to private information. Journal of Financial Economics, v. 18(2): 277-311.

Diether, K.; Lee, K. \& Werner, I. (2009). It's SHO Time! Short-Sale Price Tests and Market Quality. The Journal of Finance. v. 64 (1): 37-73

Duffie, D.; Garleanu, N. \& Pedersen, L.H. (2002). Securities lending, shorting, and pricing. Journal of Financial Economics, v. 66 (3): 307-339.

Fotak, V. Raman, V. \& Yadav, P. (2014). Fails-todeliver, short selling, and market quality, Journal of Financial Economics, v. 114 (3): 493-516.

Gilchrist, S.; Himmelberg, C. \& Huberman, G. (2005). Do stock price bubbles influence corporate investment? Journal of Monetary Economics, 52: 805-27.

Goldstein, I. \& Guembel, A. (2008). Manipulation and the allocational role of prices. Review of Economic Studies, v. 75: 133-64.

Grullon, G.; Michenaud, S. \& Weston, J. (2015) The Real Effects of Short-Selling Constraints. The Review of Financial Studies, v.28 (6): 1737-1767

Jones, C. \& Lamont, O. (2002). Short-sale constraints and stock returns. Journal of Financial Economics, v. 66(2-3): 207-239.
Kaplan, S.; Moskowitz, T. \& Sensoy, B. (2013). The Effects of Stock Lending on Security Prices: An Experiment. The Journal of Finance, v.68 (5): 1891-1936.

Miller, E. (1977) Risk, uncertainty, and divergence of opinion, Journal of Finance, v. 32: 1151-68.

Mota, L. (2017). Stock Lending Market, ShortSelling Restrictions, and the Cross-Section of Returns. Doctoral Thesis, EPGE/FGV. Rio de Janeiro.

Ofek, E. \& Richardson, M. (2003). DotCom Mania: The Rise and Fall of Internet Stock Prices. The Journal of Finance, v. 58 (3): 1113-1137.

Ofek, E., Richardson, M., \& Whitelaw, R. (2004). Limited arbitrage and short sales restrictions: Evidence from the options markets. Journal of Financial Economics, 74(2), 305-342.

Saff, P. \& Sigurdsson, K. (2011), Price efficiency and short selling, Review of Financial Studies, v. 24: 821-852. 
Authors:

1. Fernando Chague, Ph.D in Economics - University of North Carolina at Chapel Hill, North Carolina, USA. E-mail: fernando.chague@fgv.br

\section{ORCID}

(i) 0000-0002-1366-9120

2. Rodrigo De Losso, Ph.D in Economics - University of Chicago, Illinois, USA. E-mail: delosso@usp.br ORCID

(iD) 0000-0002-3461-8621

3. Alan De Genaro, Doctorate in Statistics - Institute of Mathematics and Statistics - USP, São Paulo, Brazil. E-mail: alan.genaro@fgv.br

ORCID

(iD) 0000-0002-9839-6116

4. Bruno Giovannetti, Ph.D in Economics - Columbia University, New York, USA.

E-mail: bruno.giovannetti@fgv.br

\section{ORCID}

(iD 0000-0003-0021-8539

\section{Contribution of each author}

\begin{tabular}{|c|c|c|c|c|}
\hline Contribution & $\begin{array}{c}\text { Fernando } \\
\text { Chague }\end{array}$ & $\begin{array}{l}\text { Rodrigo } \\
\text { De Losso }\end{array}$ & $\begin{array}{c}\text { Alan De } \\
\text { Genaro }\end{array}$ & $\begin{array}{c}\text { Bruno } \\
\text { Giovannetti }\end{array}$ \\
\hline 1. Definition of research problem & $\sqrt{ }$ & $\sqrt{ }$ & $\sqrt{ }$ & $\sqrt{ }$ \\
\hline 2. Development of hypotheses or research questions (empirical studies) & $\sqrt{ }$ & $\sqrt{ }$ & $\sqrt{ }$ & $\sqrt{ }$ \\
\hline 3. Development of theoretical propositions (theoretical work) & $\sqrt{ }$ & $\sqrt{ }$ & $\sqrt{ }$ & $\sqrt{ }$ \\
\hline 4. Theoretical foundation/Literature review & $\sqrt{ }$ & $\sqrt{ }$ & $\sqrt{ }$ & $\sqrt{ }$ \\
\hline 5. Definition of methodological procedures & $\sqrt{ }$ & $\sqrt{ }$ & $\sqrt{ }$ & $\sqrt{ }$ \\
\hline 6. Data collection & & $\sqrt{ }$ & $\sqrt{ }$ & $\sqrt{ }$ \\
\hline 7. Statistical analysis & $\sqrt{ }$ & $\sqrt{ }$ & $\sqrt{ }$ & $\sqrt{ }$ \\
\hline 8. Analysis and interpretation of data & $\sqrt{ }$ & $\sqrt{ }$ & $\sqrt{ }$ & $\sqrt{ }$ \\
\hline 9. Critical revision of the manuscript & $\sqrt{ }$ & $\sqrt{ }$ & $\sqrt{ }$ & $\sqrt{ }$ \\
\hline 10. Manuscript writing & $\sqrt{ }$ & $\sqrt{ }$ & $\sqrt{ }$ & $\sqrt{ }$ \\
\hline 11. Other (supervision) & & & & \\
\hline
\end{tabular}

